\title{
Enhance Ride-Through Capability of Adjustable Speed Drives by Maintaining DC-Link voltage
}

\author{
S.S.Deswal, Ratna Dahiya, D.K.Jain
}

\begin{abstract}
Electric power quality encompasses voltage transients, sags, swells, voltage distortions and momentary interruptions (outages) etc There are different techniques to enhance ride-through capability of ASD's during voltage sag conditions. These are aimed at maintaining the DC-link voltage constant by injecting energy from an external source. Ultracapacitors, as storage device, are of reduced size as compared to batteries and provide fast energy exchange. In this paper, the improved performance of ASD's with Ultracapacitors at DC- link during various electric power system faults is demonstrated using MATLAB simulation.and physical experiments were carried out to verify the correctness and validity of proposed ASD ride through topology and control strategies. The performance of ASD under healty and abnormal condition is first simulated in MATLab simulink and then the same are verified using designed hardware setup. The LABView (8.5) software and DAQ board has been used to record the generated waveforms during various power quality disturbances.
\end{abstract}

Index Terms - Ride-through topologies, Power Quality, Adjustable speed drives, Ultracapacitors, ultracapacitors.

\section{INTRODUCTION}

Adjustable Speed Drives are susceptible to voltage sags occurring due to faults in electric power system. [1-7, 11]. The situation of poor power electric quality is more evident in countries with a weaker power grid, such as India, African countries, and other developing countries, than in the industrialized world. Nevertheless, the problem is of significance also in countries with a strong power grid. The voltage sags affect many systems and in particular, sensitive equipment, for example Adjustable-speed electrical drives (ASD's). The voltage sag event even of a small duration leads to the shutdown of the industrial drive and the process stops, leading to lost time, material and financial losses. ASD's are therefore made to tolerate the uncertainty of the power supply with variations in the voltage. Some common symptoms of PQ problems in ASD systems are:

$\ddot{y}$ The ASD prematurely trips or shuts down.

$\ddot{y}$ The ASD resets or restarts.

$\ddot{y}$ The ASD, requires frequent repairs or replacements.

$\ddot{y}$ The erratic control of process parameters.

S.S. Deswal is with the Department of Electrical and Electronics Engineering, Maharaja Agrasen Institute of Technology, Rohini, Delhi, India

Mrs.Ratna Dahiya is with the Department of Electrical Engineering. National Institute of Technology, Kurukshetra, Haryana, India

D.K.Jain, is with the Department of Electrical Engineering, Deen Bandhu Chhotu Ram University of Science and Technology, Murthal, Sonipat, India $\ddot{y}$ The unexplained fuse blowing and/or component failures.

$\ddot{y}$ The frequent motor overheating trip and/or continuous operation of the motor cooling system.

Although, there are number of power quality problems such as transients, interruption, sag/under-voltage, swell/ over- voltage, waveform distortion, voltage fluctuations and frequency variations; voltage sag is the major reason for ASDs' shutdown. Voltage sag is a reduction of AC voltage at a given frequency for the duration of 0.5 cycles to 1 minute's time. Common causes of sags include starting large loads and remote fault clearing performed by utility equipment. Similarly, the starting of large motors inside an industrial facility can result in significant voltage drop (sag).

In order for an ASD to ride-through a disturbance at full-power, an energy storage device is needed to act as a backup power source. A number of options are available, with batteries and flywheel systems being able to provide ride-through for up to an hour. The major disadvantages of batteries and flywheel systems are their size and maintenance requirements, but batteries are currently a cheap option. Fuel cells can store a large amount of energy but can not respond quickly. SMES systems can provide reasonable ride-through capabilities, but require sophisticated cooling systems. Ultracapacitors can respond quickly to voltage fluctuations, have a long lifetime, require no maintenance, and can be easily be monitored due to the fact that their state of charge is dependent on the voltage [12]. The choice of energy storage option will largely depend upon the power requirement and the desired ride-through time (Fig. 1). It is obvious that ultracapacitors are an advantageous choice for ride-through times of up to 5 seconds and up to a rating of $100 \mathrm{kVA}$.

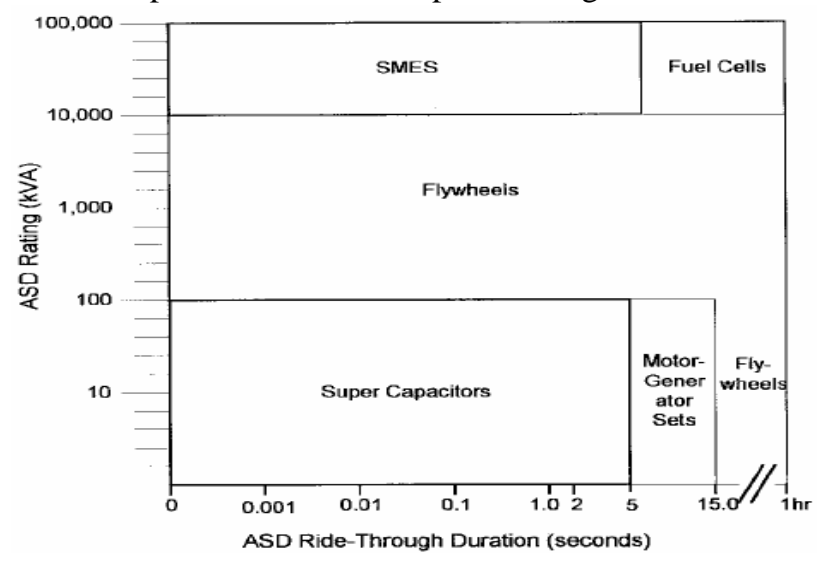

Fig 1 - Energy storage options for different ASD power ratings 


\section{Classification OF Different Types of Voltage SAGS/DIPS AND THEIR IMPACT ON ASD's}

The voltage dips can be classified into seven groups. The following types exist and described in Fig.2 and Fig.3.

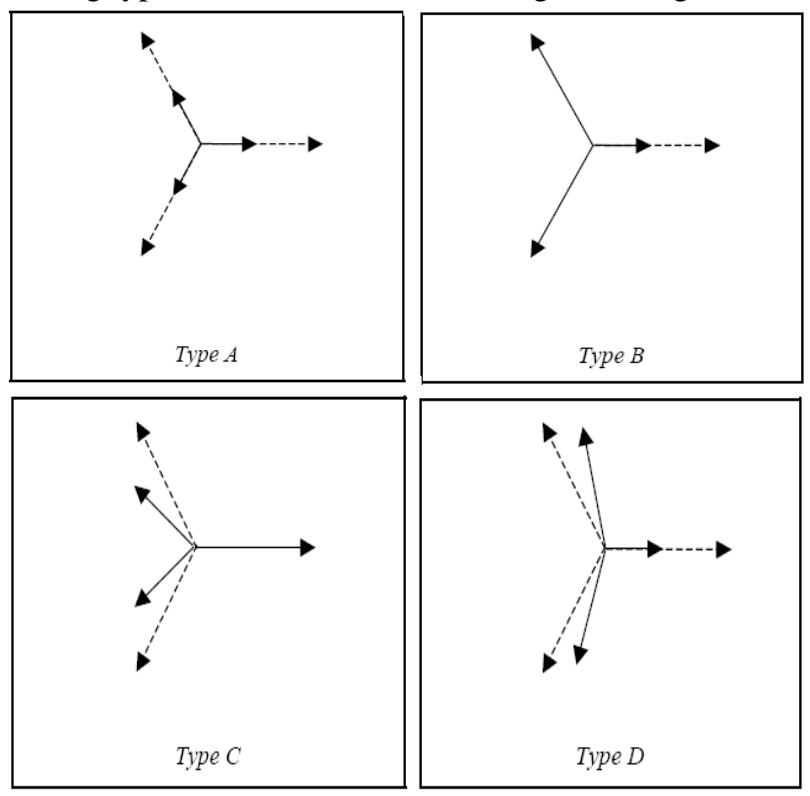

Fig.2. Four types of voltage dips due to one- or three-phase fault.

A balanced three-phase voltage dip will result in a type A. Since the voltage dip is balanced, the zero-sequence is zero, and a transformer will not affect the appearance of the voltage dip. This holds both for the phase-ground voltage and phase-to-phase-voltage.

A phase-to-ground-fault will result in a type $B$.

If there is a transformer that removes the zero-sequence between the fault location and the load, the voltage dip will be of type $D$.

A phase-to-phase-fault results in a type $C$. The resulting voltage dip types caused by different fault are listed in Table 1.

The voltage dips of type $E, F$ and $G$ are due to a two-phase-to-ground fault. An overview of the different types of voltage dips due to a two phase- to-ground faults is shown in Table 2.

A voltage dip is usually caused by an un-symmetrical fault. To calculate the voltage dip propagation, the use of symmetrical components is recommended.

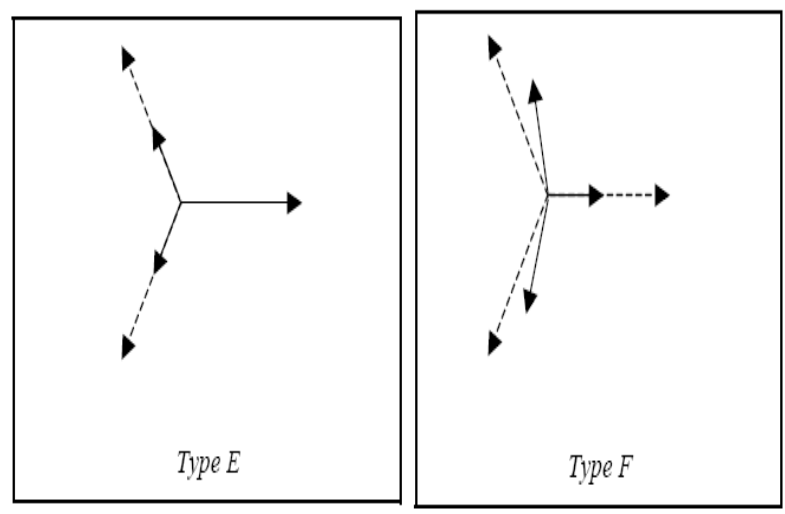

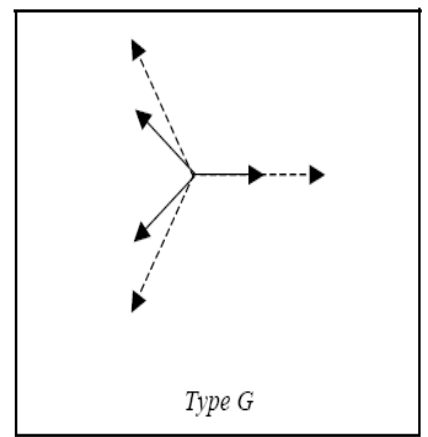

Fig.3. Three types of voltage dips due to two- phase fault.

The sensitivity of AC ASD's to voltage sags is presented in a voltage tolerance curve as shown in Fig. 4 as per IEEE Std. 1346[2]. It may be seen that the ASD's can withstand a reduction in the line voltage upto $85 \%$ of nominal value for an extended duration of time. This Fig may change, depending on the sensitivity of the process controlled by the drive. For all points falling below the voltage tolerance curve, the drive will trip [9-10].

\section{HP ASD (PWM) Voltage Sag Tolerance Curves}

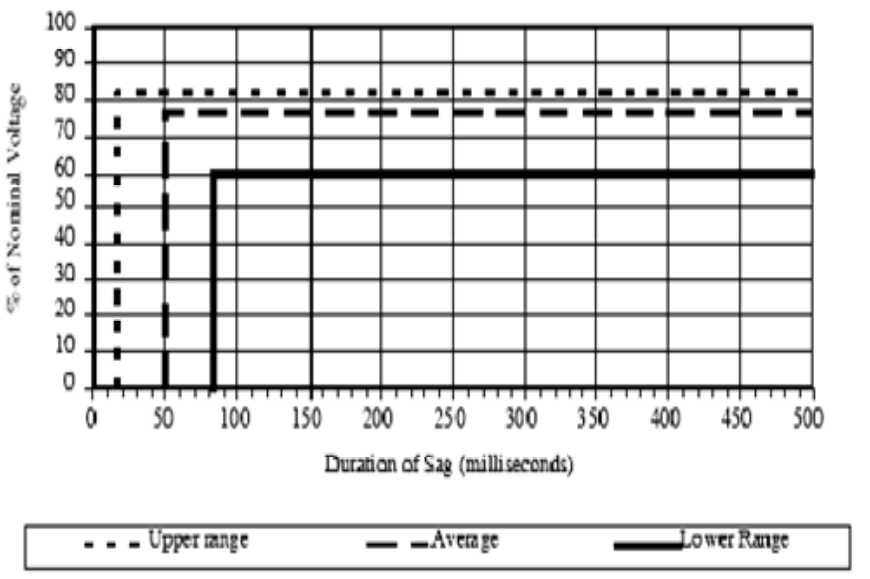

Fig. 4. Voltage tolerance curve of an ASD's (IEEE Std.1346)

\section{DIFFERENT RIDE Through ALTERNATIVES AND THEIR COMPARISON}

By adding capacitors to the DC- link, additional energy needed for full-power ride-through during voltage sag can be provided to the motor. It is a simple and rugged approach, which can provide limited ride-through for minor disturbances. However, its cost is relatively high and a large cabinet space is required. The load inertia may be utilized to provide ride- through capability to ASD's. The inverter control software can be modified such that when a power disturbance causes the DC- link voltage to fall below a specified value, the inverter will adjust to operate at a frequency slightly below the motor frequency, causing the motor to act like a generator. The drive will absorb a small amount of energy from the rotating load to maintain the DClink at a specified level and maintains the specified DC- link for few seconds during a dip that does not exceed $20 \%$. Here, no additional cost is included only small software modification is required but provides ride-through only for sags of $20 \%$ and reduced speed may not be acceptable for 
certain loads[7-8].

TABLE. 1. OVERVIEW OF DIFFERENT TYPES OF VOLTAGE DIPS DUE TO THREE-PHASE, TWO-PHASE OR SINGLE-PHASE- TO-GROUND -FAULT

\begin{tabular}{ll} 
Dip Type & Fonit Type \\
\hline Type A & Three phase \\
Type B & Single phase to ground \\
Type C & Fhase to phase \\
Type D & Fhase to phase faults experienced by a del to \\
& Connected load), \\
& Single phase to ground(zero sequence components \\
& removed) \\
\hline
\end{tabular}

TABLE. 2. OVERVIEW OF DIFFERENT TYPES OF VOLTAGE DIPS DUE TO TWO-PHASE- TO-GROUND -FAULT

\begin{tabular}{ll} 
Dip Type & Foult Type \\
\hline Type E & Two-Phase to phase faulte expenienced by a Wye- \\
& Connected load) \\
Type F & Two-Phase to phase faultexpenienced by a Delta- \\
& Connected load) \\
Type G & Two-Phase to phase faults(experienced by a load connected \\
& Via a non-grounded transformer removing the zero sequence \\
& component)
\end{tabular}

A boost converter can be used between the rectifier and the DC- link capacitors to maintain the DC- link voltage during voltage sag. During voltage sag, the boost converter will sense a drop in the DC-link voltage and begin to regulate the DC- link to the minimum voltage required by the inverter. Boost converter provides ride-through with lower cost, upto $50 \%$ sag but fails during outages. Replacing the diode rectifier with an active PWM rectifier regulates the DC- link which offers immunity to voltage sags and transients and low input current harmonics. The range of ride through provided by this approach is limited only by the current rating of the rectifier. Active rectifier with lower cost provides ride-through up to $50 \%$ sag but fails during outages.

Battery backup systems operate similarly to adding capacitive energy storage, with the advantage that their energy per volume ratio is much higher than standard capacitors. The ASD's may be provided with battery backup as an add on module on the DC- link. The batteries are easily available with low cost, provide ride-through for deep sags and full outages [5]. These have low life and require additional space and maintenance.

Flywheels, which store kinetic energy in a rotating mass, are also showing promise for ASD's ride-through. Flywheels are suitable for $1 \mathrm{~kW}-10 \mathrm{MW}$ applications, and can provide full-power ride-through for up to $1 \mathrm{hr}$. [17]

Superconducting Magnetic Energy Storage (SMES) is based on the principle that energy stored in the field of a large magnetic coil can be converted quickly back to electric current as needed for various applications. A SMES unit can be applied directly connected to the DC- link of ASD's or to a number of ASD's which share a common DC- link. SMES with little maintenance provides good ride-through for long duration but it is costly and requires sophisticated cooling system to maintain cryogenic temperatures and the associated power loss.

A fuel cell could be interfaced with the ASD's DC- link to provide appropriate backup power for an individual. However, the fuel cells are costly and may be used in near future $[5,8,10]$.

\begin{tabular}{|c|c|c|c|c|c|c|}
\hline $\begin{array}{l}\text { ASD Ride- } \\
\text { Through } \\
\text { Alternatives }\end{array}$ & $\begin{array}{c}\text { Cost } \\
\text { Rs./K } \\
\text { W }\end{array}$ & $\begin{array}{c}\text { Ride-Th } \\
\text { rough } \\
\text { Duratio } \\
\text { n Limit }\end{array}$ & $\begin{array}{l}\text { Power } \\
\text { Range }\end{array}$ & $\begin{array}{l}\text { Effici } \\
\text { ency }\end{array}$ & $\begin{array}{l}\text { Cycle } \\
\text { Life }\end{array}$ & $\begin{array}{c}\text { Charging } \\
\text { Time }\end{array}$ \\
\hline $\begin{array}{l}\text { Additional } \\
\text { Capacitors* }\end{array}$ & 30000 & $0.1 \mathrm{sec}$ & $100 \mathrm{kw}$ & $95 \%$ & 10000 & Seconds \\
\hline Load Inertia & $\approx 0$ & $2.0 \mathrm{sec}$. & $\begin{array}{c}1 \mathrm{kw}-1 \\
\mathrm{mw}\end{array}$ & --- & --- & $\begin{array}{c}\text { Continue } \\
\mathrm{s}\end{array}$ \\
\hline $\begin{array}{l}\text { Reduced } \\
\text { Speed/Load }\end{array}$ & $\approx 0$ & $\begin{array}{l}0.01 \\
\text { sec. }\end{array}$ & $\begin{array}{c}5-10 k \\
w\end{array}$ & --- & -- & --- \\
\hline $\begin{array}{l}\text { Lower } \\
\text { Voltage } \\
\text { Motors* }\end{array}$ & $\approx 0$ & $\begin{array}{l}0.01 \\
\text { sec. }\end{array}$ & $\begin{array}{c}5-10 k \\
w\end{array}$ & --- & --- & -- \\
\hline $\begin{array}{l}\text { Boost } \\
\text { Converter** }\end{array}$ & $\begin{array}{c}5000-1 \\
0000\end{array}$ & $5.0 \mathrm{sec}$. & $\begin{array}{c}5-200 k \\
w\end{array}$ & $90 \%$ & --- & --- \\
\hline $\begin{array}{l}\text { Active } \\
\text { Rectifier** }\end{array}$ & $\begin{array}{c}5000-1 \\
0000\end{array}$ & 5.0 sec. & $\begin{array}{c}5-200 k \\
w\end{array}$ & --- & --- & --- \\
\hline $\begin{array}{l}\text { Battery } \\
\text { Backup* }\end{array}$ & $\begin{array}{c}5000-1 \\
0000\end{array}$ & $\begin{array}{c}5.0 \mathrm{sec} . \\
1 \mathrm{hr} .\end{array}$ & $\begin{array}{c}5 \mathrm{kw}-1 \\
\mathrm{MW}\end{array}$ & $\begin{array}{c}70-90 \\
\%\end{array}$ & 2000 & Hours \\
\hline $\begin{array}{l}\text { Ultra } \\
\text { Capacitors* }\end{array}$ & $\begin{array}{l}15000- \\
20000\end{array}$ & $5.0 \mathrm{sec}$ & $\begin{array}{c}5-100 k \\
w\end{array}$ & $90 \%$ & 10000 & Seconds \\
\hline $\begin{array}{l}\text { Motor-Gener } \\
\text { ator Sets }{ }^{*}\end{array}$ & $\begin{array}{l}10000- \\
15000\end{array}$ & $\begin{array}{l}15.0 \\
\text { sec. }\end{array}$ & $100 \mathrm{kw}$ & $70 \%$ & --- & --- \\
\hline Flywheels* & $\begin{array}{l}10000- \\
15000\end{array}$ & $\begin{array}{l}15.0 \\
\text { sec., } \\
1 \mathrm{hr} .\end{array}$ & $\begin{array}{l}1 \mathrm{kw}-1 \\
0 \mathrm{MW}\end{array}$ & $90 \%$ & 10000 & Minutes \\
\hline SMES $^{*}$ & $\begin{array}{l}30000- \\
40000\end{array}$ & $\begin{array}{l}10.0 \\
\text { sec. }\end{array}$ & $\begin{array}{l}300-10 \\
00 K W\end{array}$ & $95 \%$ & 10000 & $\begin{array}{l}\text { Minutes-h } \\
\text { ours }\end{array}$ \\
\hline Fuel Cells* & 75000 & $1 \mathrm{hr}$. & $\begin{array}{l}10 \mathrm{~kW}- \\
2 \mathrm{MW}\end{array}$ & $\begin{array}{c}40-50 \\
\%\end{array}$ & $\begin{array}{c}\text { contin } \\
\text { ues }\end{array}$ & continues \\
\hline \multicolumn{7}{|c|}{$\begin{array}{l}\text { * } \text { provides Full-power ride-through } \\
{ }_{*} \text { provide full-power ride-through for single-phase sags }<50 \%\end{array}$} \\
\hline
\end{tabular}

Ultracapacitors are new generation energy storage devices, which are true capacitors in the sense that energy is stored via charge separation at the electrode-electrolyte interface, and they can withstand a large number of charge/discharge cycles without degradation. The major advantages of Ultracapacitors include higher capacitance density, higher charge-discharge cycles, reliable, long life, and maintenance-free operation, environmentally safe, wide range of operating temperature, high power density and good energy density, so they are a good alternative. Ultracapacitors fill the gap between standard batteries and traditional capacitors for high-power, short-duration energy storage [5].

Ultracapacitors offers many advantages for providing ride-through capabilities as given in Table.3 [15-24].

TABLE.3. COMPARISON OF DIFFERENT ASD's RIDE-THROUGH ALTERNATIVES 


\section{PROPOSED RIDE-THROUGH TOPOLOGIES}

The proposed ride-through topology has been shown in fig.5. The hardware has been designed and experimental results have been taken. The designed experimental module consists of ultracapacitor bank as an energy storage device having 208 Maxwell PowerCache 25 F ultracapacitors connected in series. Each unit has a voltage of $2.7 \mathrm{~V}$ and an ESR of $0.85 \mathrm{~m} \Omega$. The EDLCs are grouped into modules of 05 cells each, and voltage balancing is managed by active circuitry in each module.

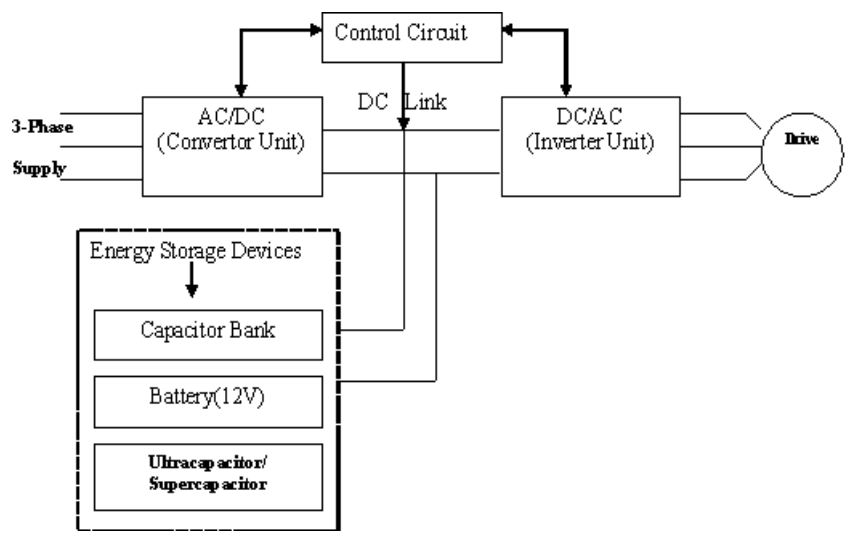

Fig. 5 Topology based on designed hardware

\section{IMPROVED PERFormance OF AdJUSTABLE SPEED DRIVES DURING FAULT CONDITIONS}

In order to compensate the voltage sags at the DC-link of ASD's boost converters can be used along with Ultracapacitor as an energy storage device. These are connected in parallel with the DC-link as shown in Fig. 6(b). Once the voltage sag takes place, the boost converter regulates the DC-link voltage to a preset DC-link voltage (the minimum safe voltage limit or higher, depending on the application). It is capable of providing ride-through for voltage sags up to $50 \%$. This technique is able to provide ride-through during an outage or during symmetrical or unsymmetrical. Hence, the ASD's remains in running mode during the disturbance [21-24].

\section{RESULTS AND DISCUSSION}

To study the improved performance of ASD's, MATLAB Simulink Power System Block-set Toolbox Demo was modified as shown in Fig. 6 and an Hardware based experimental setup was developed as shown in fig.2. The ASD's is a direct torque controlled (DTC) induction motor (specifications are given in Appendix) and is having an integrated Ultracapacitors at DC-link. The objective of this section is to investigate the performance of an ASD's under various power system faults. Fig. 7-8 \& Fig.9-10 shows the performance of the proposed scheme based on MATLAB simulation and designed experimental setup respectively. The parameters Vabc or Vryb, Iabc or Iryb, Te, Nr, Vr, Vy, $\mathrm{Vb}$, Ir, Iy, Ib and Vdc, show the three- phase source voltages, line currents, electromagnetic torque, rotor speed, voltage $\&$ current in R, Y B phases and DC-link voltage respectively.

\section{A. Performance of ASD's during Three-Phase Symmetrical Fault}

Fig. 7 \& Fig.9 shows the behavior of ASD's with a symmetrical fault. It can be seen that during the sag conditions, there is no source current being drawn since the DC- link voltage remains higher than the line voltages. The ASD's ride-through and runs with desired torque and the speed with constant DC- link voltage.

\section{B. Performance of ASD's during Three-Phase Unsymmetrical Fault}

Fig. 8 \& Fig.10 shows the behavior of ASD's with an unsymmetrical fault (double line to ground fault). The source currents are unbalanced. The machine becomes unstable with large variations in DC- link voltage, which are reflected in the torque pulsations. With the application of Ultracapacitors, the performance of the machine improves having small torque pulsations. However, the three phase rectifier slips into the single-phase operation during the sag period.

\section{CONCLUSIONS}

A proposed topology as shown in the paper using ultracapacitor as an energy storage device is developed and tested. The proposed topology is capable of providing ride through for deep voltage sags as well as short voltage interruptions by maintaining the dc link voltage level constant. Hence, the ASD's remains in running mode even during the disturbance The effectiveness of the proposed ride through topology is shown by means of simulations and experimental results obtained on a laboratory prototype. From these results is clear that the ultracapacitor dynamic response is fast enough to respond to the load transient requirements and avoid the effects of the voltage sags on the adjustable speed drive.

\section{APPENDIX}

Simulation Circuit :

Induction Motor rating and parameters:

124.3 kW, 415 volts(L-L), 3- Phase, 4 Poles, 60 Hz, 1450 rpm.

Stator resistance $\quad=\quad 0.015 \mathrm{ohm}$

Stator leakage reactance $=0.095 \mathrm{ohm}$,

Rotor resistance $\quad=0.009 \mathrm{ohm}$,

Rotor leakage reactance $=0.095 \mathrm{ohm}$,

Magnetizing reactance $=4.584 \mathrm{ohm}$,

Rotor inertia = $\quad 3.1 \mathrm{~kg} \cdot \mathrm{m} 2$.

DC- link capacitor: $\quad=\quad 300 \mathrm{~F}$,

DC- link voltage $\quad=\quad 620$ volts

Experimental Setup:

Induction Motor rating and parameters:

1HP, 415 volts(L-L), 3-Phase, 4 Poles, 50 Hz, 1444 rpm, 1.8 A.

Ultracapacitor(05 in series) $=25 \mathrm{~F} / 2.7 \mathrm{~V}$ (each)

DC- link voltage $\quad=300$ volts

Capacitor Bank $(04$ in parallel $)=560 \mathrm{Mf} / 400 \mathrm{~V}$ each 

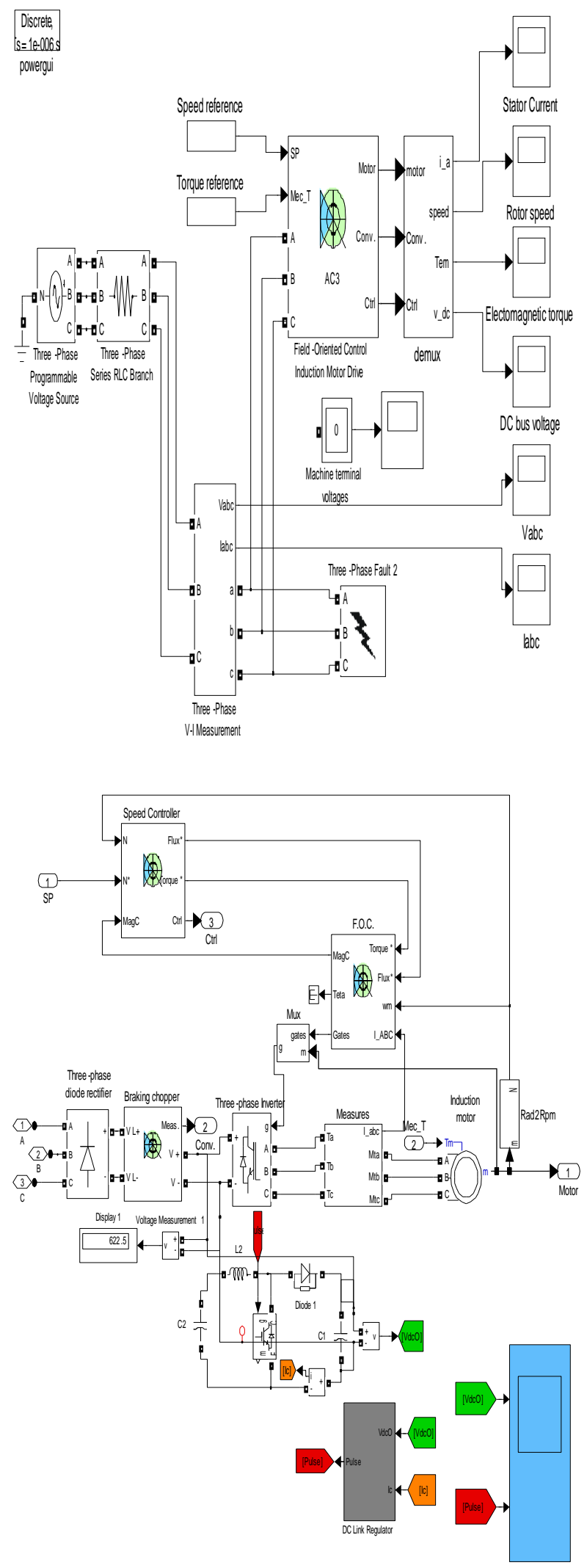

Fig. 6. MATLAB simulation of ASD's with Ultracapacitor at DC- link (a). System Simulation

(b). Drive supply details with DC-DC boost converter with Ultracapacitor
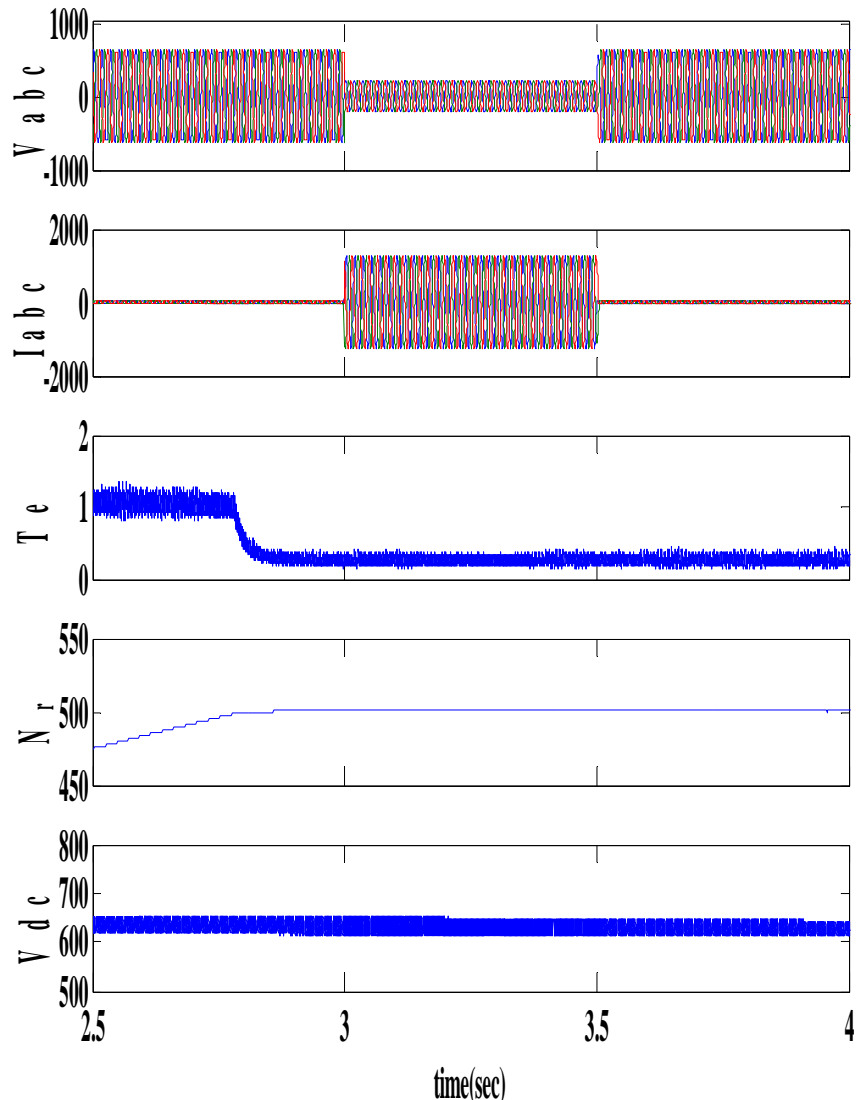

Fig. 7. Performance of ASD's during three phase symmetrical fault (Simulation results)
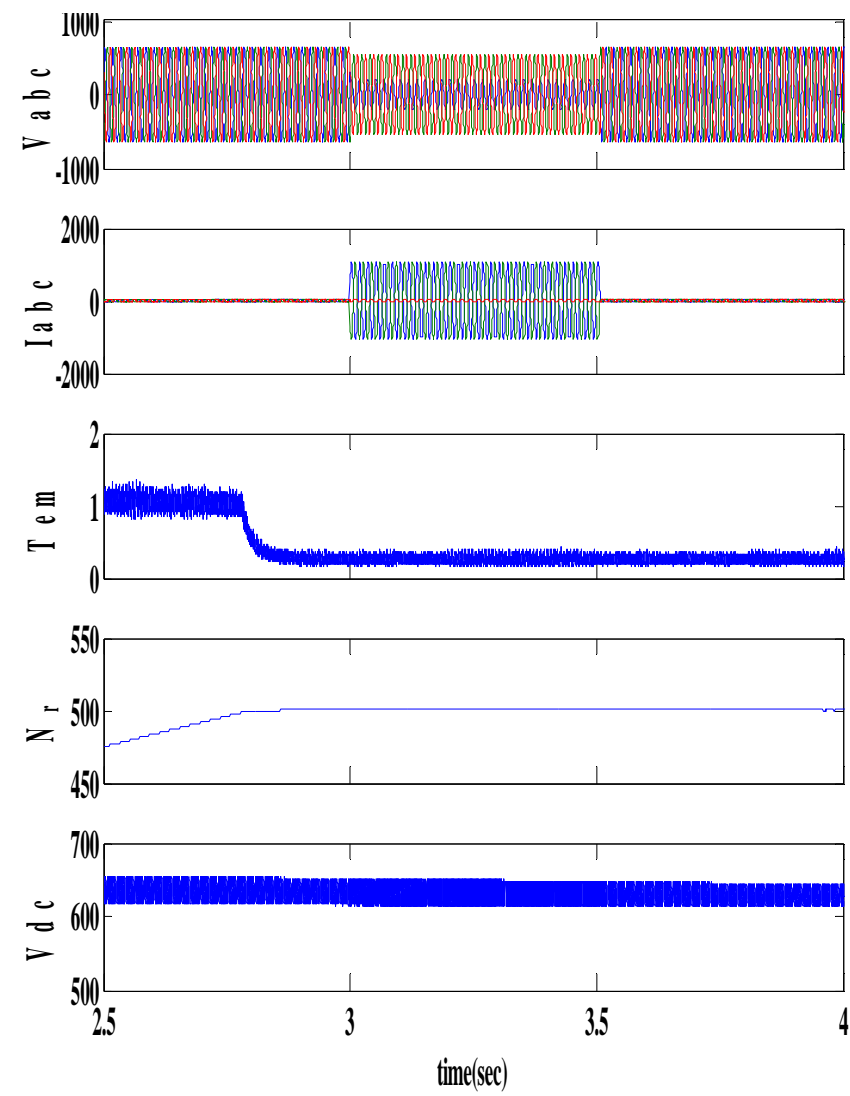

Fig. 8. Performance of ASD's during double line ground fault (Simulation results) 


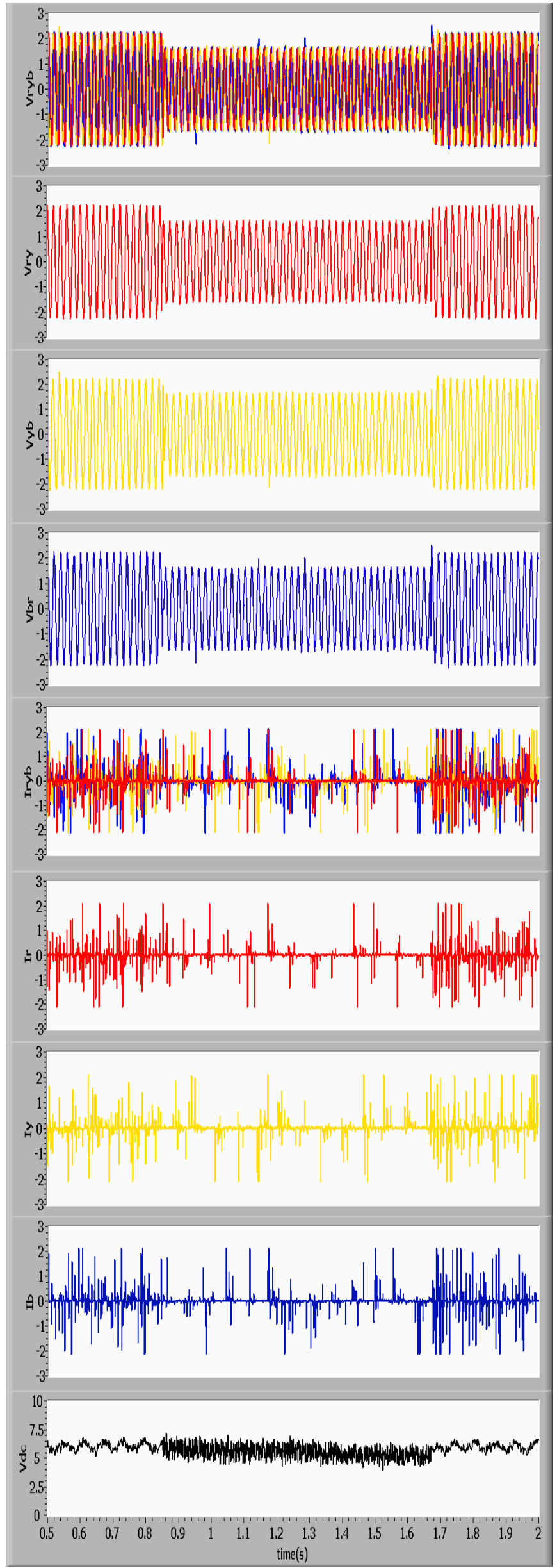

Fig. 9. Performance of ASD's during double line ground fault (Experimental results)

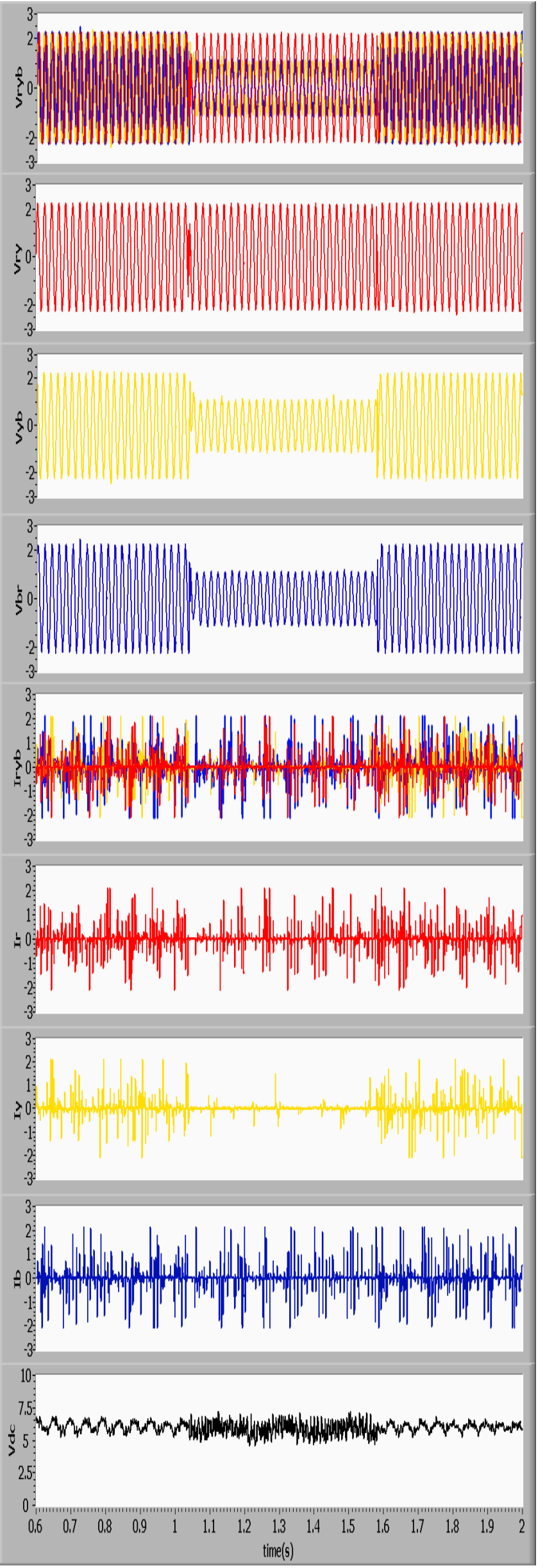

Fig. 10. Performance of ASD's during double line ground fault (Experimental results) 


\section{REFERENCES}

[1] H.G. Sarmiento and E. Estrada, "A voltage dip study in an industry with adjustable speed drives, ” IEEE Industry Applications Magazine., Vol. 2, pp. 16-19, January/February 1996.

[2] K. Stockman, F. D'hulster, K. Verhaege, J. Desmet, R. Belmans, "Voltage dip immunity test set-up for induction motor drives, " Proceedings of the 11th International Symposium on Power Electronics Ee2001, Novi Sad, Yugoslavia, October 31-November 2 , 2001 pp. 303-307.J.L.

[3] M.H.J. Bollen and L.D. Zhang, "Analysis of voltage tolerance of AC adjustable-speed drives for three-phase balanced and unbalanced dips, " IEEE Transactions on Industry Applications, Vol. IA-36, no.3, May/June 2000, pp. 904-910.

[4] M.H.J. Bollen, "Characterization of voltage dips experienced by three-phase adjustable-speed drives, " IEEE Transactions on Power Delivery, Vol. PD-12, no.4, October 1997, pp.1666-1671.

[5] Duran-Gomez, P.N. Enjeti and B. Ok Woo, "Effect of voltage dips on adjustable-speed drives: a critical evaluation and an approach to improve performance, " IEEE Transactions on Industry Applications, Vol. IA-35, no.6, November/December 1999, pp.1440-1448.

[6] J. Amantegui, F. Pazos, "Voltage dip measurement capaign in Spanish MV systems prelimenary results 1996-1998, " CCO2 Paris 1998

[7] R.A. Epperly, F.L. Hoadley and R.W. Piefer, "Considerations when applying ASD's in continuous processes, " IEEE Transactions on Industry Applications, Vol. IA-33, no.2, March/April 1997, pp. 389-396.

[8] IEEE Recommended Practices on Monitoring Electric Power Quality, IEEE Std.1159, 1995.

[9] IEEE Recommended Practices for Evaluating Electric Power System Compatibility With Electronic Process Equipment, IEEE Std.1346, 1998.

[10] M. H. J. Bollen, "Understanding Power Quality Problems: Voltage Sags and Interruptions", Series on Power Engineering. New York: IEEE Press, 2000.

[11] G.T. Heydt, Electric Power Quality, 2nd ed. WestLafayette, Stars in a Circle, 1994

[12] A. Von, P.N. Enjeti, B. Banerjee, "Assessment of Ride-Through Alternatives for Adjustable-Speed Drives", IEEE Trans. on Industry Application vol. 35, issue 4, pp. 908 - 916, July-Aug. 1999.

[13] K. Lee, T.M. Jahns, D.W. Novotony, T.A. Lipo, W.E. Berkopec, and V. Blasko, "Impact of Inductor Placement on the Performance of Adjustable-Speed Drives Under Input Voltage Unbalance and Sag Conditions", IEEE Trans. on Industry Applications, vol. 42, No. 5, pp. 1230-1240, Sept./Oct. 2006.

[14] M. Sullivan, T. Vardell, and M. Johnson, "Power Interruption Costs to Industrial and Commercial Consumers of Electricity", IEEE Trans. on Industry Applications, vol. 33, pp. 1448-1458, Nov./Dec. 1997.

[15] A. Z. Van. R. Spee, A. Faveluke and S. Bhowmik, "Voltage Sag Ride-Through for Adjustable-Speed Drives With Active Rectifiers", IEEE Trans. on Industry Applications, vol. 34, issue 6, pp. 1270 - 1277 Nov.-Dec. 1998.

[16] J. L. Duran-Gomez, P. N. Enjeti, and B. O. Woo, "Effect Of Voltage Sags on Adjustable Speed Drives-A Critical Evaluation and an Approach to Improve Its Performance", IEEE Trans. on Industry Applications, vol. 35, pp. 1440-1449, Nov./Dec. 1999.

[17] J. L. D. Gomez, P.N. Enjeti, A. J. Von, ”An Approach to Achieve Ride-Through of an Adjustable-Speed Drive with Fly back Converter Modules Powered by Super Capacitors", IEEE Trans. on Industry Applications, vol. 38, issue 2, pp. 514-522 March-April 2002.

[18] L. Palma, P. Enjeti, E. Aeloiza, "An Approach to Provide Ride-Through for ASD Systems with Ultracapacitors", IEEE Power Electronics Congress, pp. 182-187, Oct. 2002.

[19] F. D. Silva, A. J. J. Rezek, A. A. P Junior, L. E. B. D. Silva, P. C. Rosa, and L. O. M. Reis, "Ultracapacitor-Based Ride-Through System for Adjustable Speed Drives Applied to Critical Process", IEEE conference on Harmonics and Quality of Power, vol. 2, pp. 632-638, 2002.

[20] Y.R.L. Jayawickrama and S. Rajakaruna, "Ultracapacitor Based Ride-Through System for a DC Load", IEEE Conference on Power System Technology, vol. 1, pp. 232-237, 2004.

[21] S.S.Deswal, et.al, "Ride-Through Topology for Adjustable Speed Drives (ASD's) During Power System Faults", has been published in International Journal of Computer Science, Informatics and Electrical Engineering (JCSIEE), vol.2, issue 1, 2008.

[22] S.S.Deswal, et.al, "Application of Boost Converter For Ride-through Capability of Adjustable Speed Drives during Sag and Swell Conditions", has been published in International Journal of Electrical and Electronics Engineering (IJEEE), vol.4, issue 3, 2009(pp-184-188)

[23] S.Dahiya. D.K.Jain. Ashok Kumar, R.Dahiya, S.S.Deswal, "Ride-through Capabilities of ASD's Using Ultracapacitors", Proceedings of 8th International Power Engineering Conference (IPEC-07), pp-714-719, Singapore, 2007.

[24] S.S.Deswal, et.al, "Improvement of Adjustable Speed Drives(ASD's) performance during sag condition using Ultracapacitor's", has been published in an International conference (POWERCON-2008) held at

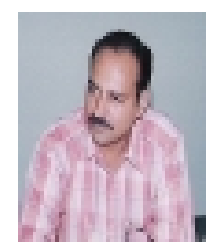
New Delhi in Oct-2008.

S.S.Deswal received his B.Tech degree in Electrical Engineering from R.E.C, Kurukshetra, Kurukshetra University, Haryana, India in 1998, the M.E degree in Electrical Engineering(Power Apparatus and Systems) from Delhi College of Engineering, Delhi University, Delhi, India in 2005, and is currently pursuing the $\mathrm{Ph} . \mathrm{D}$. degree from N.I.T, Kurukshetra a Deemed University, Haryana, Delhi. Currently, he is working as a Senior Lecturer in EEE Department with the Maharaja Agrasen Institute of Technology, Rohini, Delhi under GGSIP University, Delhi, India. Before joining MAIT in 2006, he was with C.R.Institute of Technology, Kanjhawala, Delhi and was working as Head of the Electrical and Instrumentation Control Department, from 1998 to 2006. His research interests include ASD's, power quality, motor drives, Renewable energy.

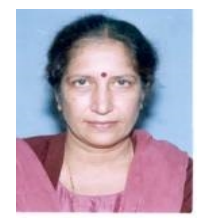

Dr.Ratna Dahiya received her B.Tech from GBU, Pant Nagar and M.Tech and Ph.D. degree degree in Electrical Engineering from R.E.C, Kurukshetra, Kurukshetra University, Haryana, India. Currently, she is working as Asstt.Prof. in Electrical Engineering Department with the NIT, Kurukshetra (Deemed University), Haryana, India. Her research interests include SMES, Induction Machines, ASD's, power quality, motor drives, Renewable energy.

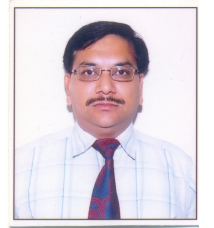

energy systems.
Dr.D.K.Jain received his B.Tech, M.Tech and Ph.D. degree in Electrical Engineering from Regional Engineering College, Kurukshetra University, India. Currently, he is working as Director Guru Prem Sukh Memorial College of engineering under GGSIP University, Delhi, India. His research interests include electric power quality, motor drives, and renewable 